\title{
Duplication of 10 Nucleotides in the Erythroid Band 3 (AE1) Gene in a Kindred with Hereditary Spherocytosis and Band 3 Protein Deficiency (Band $3^{\text {PRAGUE}}$ )
}

\author{
Petr Jarolim, * Hillard L. Rubin, * Shih-Chun Liu, * Michael R. Cho, 5 Vaclav Brabec, ${ }^{*}$ Laura H. Derick, * \\ Scott J. Yi, * Sara T. O. Saad, * Seth Alper," Carlo Brugnara," David E. Golan, ${ }^{3}$ and Jiri Palek* \\ * Department of Biomedical Research, Division of Hematology/Oncology, St. Elizabeth's Hospital, Tufts University School of \\ Medicine, Boston, Massachusetts 02135; ${ }^{\ddagger}$ Institute of Hematology and Blood Transfusion, 12820 Prague, Czech Republic; \\ ${ }^{\S}$ Departments of Biological Chemistry and Molecular Pharmacology and of Medicine, Harvard Medical \\ School, Hematology-Oncology Division, Brigham and Women's Hospital, "Molecular Medicine and Renal Unit, \\ Beth Israel Hospital, Department of Cellular and Molecular Physiology, Harvard Medical School, and \\ 'Department of Pathology and the Clinical Laboratories, The Children's Hospital, Boston, Massachusetts 02115
}

\begin{abstract}
We describe a duplication of 10 nucleotides $(2,455-2,464)$ in the band 3 gene in a kindred with autosomal dominant hereditary spherocytosis and a partial deficiency of the band 3 protein that is reflected by decreased rate of transmembrane sulfate flux and decreased density of intramembrane particles. The mutant allele potentially encodes an abnormal band 3 protein with a 3.5-kD COOH-terminal truncation; however, we did not detect the mutant protein in the membrane of mature red blood cells. Since the mRNA levels for the mutant and normal alleles are similar and since the band 3 content is the same in the light and dense red cell fractions, we conclude that the mutant band 3 is either not inserted into the plasma membrane or lost from the membrane prior to the release of red blood cells into circulation. We further show that the decrease in band 3 content principally involves the dimeric laterally and rotationally mobile fraction of the band 3 protein, while the laterally immobile and rotationally restricted band 3 fraction is left essentially intact. We propose that the decreased density of intramembrane particles decreases the stability of the membrane lipid bilayer and causes release of lipid microvesicles that leads to surface area deficiency and spherocytosis. (J. Clin. Invest. 1994. 93:121130.) Key words: erythrocyte membrane band 3 protein - congenital hemolytic anemia - frameshift mutation - density gradient centrifugation • transmission electron microscopy
\end{abstract}

\section{Introduction}

Hereditary spherocytosis (HS $)^{1}$ is a common hereditary hemolytic disorder that is heterogeneous in terms of inheritance, red

This work was presented in part at the 34th Annual Meeting of the American Society of Hematology, 4-8 December 1992, Anaheim, CA, and published in abstract form (1992. Blood. 80[Suppl. 1]:277a. [Abstr.]).

Address correspondence to Petr Jarolim, M.D., Ph.D., Department of Biomedical Research, St. Elizabeth's Hospital, 736 Cambridge St., Boston, MA 02135. Sara T. O. Saad's current address is Hemocentro, University of Campinas, PO Box 6198, Campinas, S.P., Brazil.

Received for publication 30 June 1993 and in revised form 14 September 1993

1. Abbreviations used in this paper: DIDS, di-isothiocyano-dihydrostilbene disulphonate; E5M, eosin-5-maleimide; HS, hereditary spherocytosis; IOV, inside-out vesicles; SSCP, single-strand conformation polymorphism.

J. Clin. Invest.

(c) The American Society for Clinical Investigation, Inc. $0021-9738 / 94 / 01 / 0121 / 10 \$ 2.00$

Volume 93, January 1994, 121-130 cell morphology, clinical severity, and the underlying molecular defects (1). The principal membrane protein abnormalities involve a deficiency of spectrin $(2,3)$ or a combined deficiency of spectrin and ankyrin (4) with the reported underlying mutations involving $\alpha$ spectrin (5), $\beta$ spectrin (6-8), or ankyrin (9-11). Recently, two laboratories have detected a subset of $\sim 20 \%$ of HS kindred who are deficient in the band 3 protein $(12,13)$. Restriction fragment length polymorphism study in one large family with HS and band 3 deficiency excluded linkage to $\alpha$ spectrin, $\beta$ spectrin, and ankyrin and suggested linkage to the band 3 protein (14).

Band 3 is the most abundant protein of the red cell membrane. The protein consists of two domains with separate and largely independent functions. Most of the $\mathrm{COOH}$-terminal 56-kD membrane domain consists of 12-14 membrane-spanning $\alpha$ helices connected by endo- and ectoplasmic loops. The main function of the membrane domain is to mediate anion exchange across the membrane. The $\mathrm{NH}_{2}$-terminal $45-\mathrm{kD}$ cytoplasmic domain anchors the membrane skeleton to the membrane via interactions with ankyrin, protein 4.1 , and protein 4.2 (15-19). In addition, the cytoplasmic domain binds hemoglobin and several glycolytic enzymes $(15,16,20)$.

Here, we report the first mutation of the band 3 protein that is coinherited with a dominantly inherited spherocytosis and a marked deficiency of band 3 protein in three generations. The mutation was detected by screening the coding region of patient band 3 cDNA for single-strand conformation polymorphisms (SSCP). Sequencing of cDNA and of the corresponding $3^{\prime}$ portion of the band 3 gene revealed a duplication of 10 nucleotides in one band 3 allele in all five affected family members. This frameshift duplication replaces the last 90 carboxyterminal amino acids of the normal band 3 protein with a new $\mathrm{COOH}$ terminus of 70 amino acids, which is predicted to have a low probability of spanning the lipid bilayer.

To elucidate the molecular basis of the red cell surface area deficiency in this kindred, we measured the relative number of band 3 molecules in individual red blood cells, the band 3 content in density separated erythrocytes, the sulfate flux across the membrane, the oligomeric states of the band 3 protein, the lateral and rotational mobility of the band 3 in intact red blood cells, and the distribution of intramembrane particles in the membrane. We conclude that $(a)$ the mutation leads to band 3 deficiency either by preventing the insertion or translocation of mutant band 3 to the plasma membrane during band 3 biosynthesis, or by causing a loss of mutant band 3 protein from the membrane before the release of red blood cells into the circulation; $(b)$ band 3 deficiency affects primarily the laterally and rotationally mobile dimeric fraction of band 3 


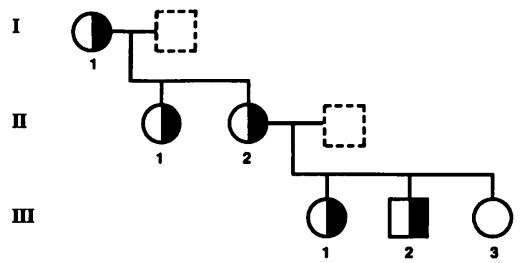

Figure 1. Pedigree of the studied family. Moderately severe hereditary spherocytosis is inherited in an autosomal dominant fashion. Only one unaffected family member III/3 was available for study; however, husbands of patients I/ 1 and II/ 1 were reportedly hematologically normal.

protein that is not associated with the underlying membrane skeleton; $(c)$ band 3 deficiency leads to a proportional decrease in anion flux across the membrane; and $(d)$ the deficiency is reflected morphologically by a decreased density of intramembrane particles. We propose that the decreased density of intramembrane particles decreases the stability of the membrane lipid bilayer and leads to release of particle- and skeleton-free lipid vesicles from the cells which, in turn, causes surface area deficiency and spherocytosis.

\section{Methods}

Case report. We have studied a family from Prague, Czech Republic (Fig. 1). Hereditary spherocytosis was diagnosed in five subjects from three generations and was inherited in an autosomal dominant fashion. Only one unaffected subject (III/3) was available for testing; however, husbands of patients I/ 1 and II / I were reportedly hematologically normal. Table I shows hematological parameters in the affected family members. Before splenectomy, the affected subjects had a compensated hemolytic disease with reticulocytosis, hyperbilirubinemia, and increased osmotic fragility. After obtaining informed consent from the studied individuals, venous blood was collected into acid citrate/dextrose solution and shipped on ice overnight to Boston for evaluation.

Preparation of erythrocyte ghosts and analysis of membrane proteins. Within $48 \mathrm{~h}$ of phlebotomy, erythrocyte ghosts were prepared by the method of Dodge et al. (21) with minor modifications described in (22). Proteins were analyzed by SDS-PAGE in $3.5-17 \%$ exponential gradient gels according to Agre's modification (2) of the original Fairbanks method (23) and in 12\% Laemmli gels (24), and the relative abundance of the major red cell membrane proteins was analyzed by densitometry.

Quantitation of band 3 copies by cytofluorometry. Band 3 protein was quantified in individual red cells by cytofluorometry of eosin-5maleimide (E5M)-labeled erythrocytes, essentially as described (25). Briefly, blood was washed three times with PBS and the buffy coat was carefully removed. $40 \mu \mathrm{l}$ of packed red cells were resuspended in 1.76 $\mathrm{ml}$ of PBS with $0.5 \%$ BSA and $200 \mu \mathrm{l}$ of a $1 \mathrm{mg} / \mathrm{ml}$ stock solution of E5M (Molecular Probes, Eugene, OR) were added. The suspension was incubated for $1 \mathrm{~h}$ in the dark at room temperature on a tube rocker, washed three times with PBS, and resuspended in PBS with 0.5\% BSA. Erythrocytes were analyzed using a flow cytometer (Profile II; Coulter Electronics Corp., Hialeah, FL). Fluorescence at $525 \mathrm{~nm}$, low angle and right angle scatter, were measured for 20,000 cells in each sample, a histogram of fluorescence intensity was plotted, and the mean fluorescence intensity and the standard deviation were calculated.

SSCP analysis of band $3 c D N A$. Total reticulocyte RNA was isolated by ammonium chloride lysis (26) and reverse transcribed using random primers. SSCP screening was performed as described $(27,28)$ with minor modifications. Briefly, cDNA was PCR amplified in overlapping fragments of $300-400 \mathrm{bp}$. To each $10 \mu \mathrm{l}$ PCR reaction, 2.5 $\mu \mathrm{Ci}\left[{ }^{32} \mathrm{P}\right] \mathrm{dATP}(3,000 \mu \mathrm{Ci} / \mathrm{mmol}$; ICN Biomedicals, Inc., Costa Mesa, $\mathrm{CA}$ ) were added. The PCR products were diluted in formamide loading buffer ( $86 \%$ formamide, $10 \%$ glycerol, $20 \mathrm{mM}$ EDTA, $0.25 \%$ bromophenol blue, and $0.25 \%$ xylene cyanol), heat denatured by boiling for $5 \mathrm{~min}$, and quickly cooled on ice. Samples were electrophoresed at 8 $\mathrm{W}$ for $16 \mathrm{~h}$ at room temperature in a nondenaturing polyacrylamide mutation detection enhancement gel $(25 \mathrm{ml}$ mutation detection enhancement gel solution prepared according to manufacturer's specifications (AT Biochem, Malvern, PA), $69 \mathrm{ml}$ deionized water, $6 \mathrm{ml} \mathrm{10 \times}$ Tris-borate/EDTA electrophoresis buffer, $0.4 \mathrm{ml} 10 \%$ ammonium persulfate, $40 \mu \mathrm{l} N, N, N^{\prime}, N^{\prime}$-tetramethylethylenediamine and the gel was exposed to Kodak XAR-5 film overnight at $-80^{\circ} \mathrm{C}$.

Sequencing of band $3 c D N A$ and genomic DNA. The segment of band 3 cDNA exhibiting the abnormal SSCP pattern was PCR-amplified using primers P298 (5'-CAGCGGCATCCAGCTCTTGA-3') and P195 (5'-GCCTTCCTTCCCCACCCA-3') and the Perkin-Elmer Cetus Instruments (Norwalk, CT) GeneAmp PCR reagents kit (35 cycles, $1 \mathrm{~min}$ at $94^{\circ} \mathrm{C}, 1 \mathrm{~min}$ at $55^{\circ} \mathrm{C}$, and $1.5 \mathrm{~min}$ at $72^{\circ} \mathrm{C}$ ). An aliquot of the PCR product was cloned into plasmid pCR II using the TA Cloning Kit (Invitrogen, San Diego, CA). 24 clones containing the PCR-amplified CDNA were prepared, pooled and sequenced on both strands using the Sequenase Version 2.0 DNA Sequencing Kit (United States Biochemical Corp., Cleveland, $\mathrm{OH}$ ). In addition, six clones were sequenced individually. A segment of the band 3 gene was PCR-amplified using primers P298 and P402 (5'-CCGCTTGACGTAGGGCACAT-3'), cloned and seven individual clones were sequenced as described above.

Detection of the 10 nucleotide insertion by PCR and quantitation of cDNA for the normal and mutant band 3 alleles. The presence of the 10 nucleotide insertion was verified in the cDNA and genomic DNA of all four additional affected family members by PCR amplification of the segment containing the insertion using flanking primers P298 and P243 (5'-TAAGTGCATGCGCCAGGTCT-3') (25 cycles, 1 min at

Table I. Selected Hematological Parameters of the Affected Family Members; Whenever Available, Data both before and after Splenectomy Are Shown

\begin{tabular}{|c|c|c|c|c|c|c|c|c|c|c|c|c|}
\hline \multirow[b]{2}{*}{ Patient } & \multirow[b]{2}{*}{ Date of birth } & \multirow[b]{2}{*}{ SE } & \multicolumn{2}{|c|}{ Hemoglobin } & \multicolumn{2}{|c|}{ Hematocrit (\%) } & \multirow{2}{*}{$\begin{array}{l}\text { Mean corpuscular } \\
\text { volume }\end{array}$} & \multicolumn{2}{|c|}{ Reticulocytes } & \multicolumn{2}{|c|}{ Bilirubin (total*) } & \multirow{2}{*}{$\begin{array}{l}\text { Osmotic } \\
\text { fragility }\end{array}$} \\
\hline & & & Before SE & After SE & Before SE & After SE & & Before SE & After SE & Before SE & After SE & \\
\hline & \multicolumn{6}{|c|}{$g / d l$} & $f l$ & & & & & \\
\hline I/1 (I.C.) & 1934 & 1975 & & 16.3 & & 46.1 & 84 & & 2.7 & & 12.1 & $0.58-0.34$ \\
\hline II/1 (I.F.) & 1959 & 1986 & & 15.5 & & 42.9 & 86 & & 1.4 & 23.0 & 16.0 & $0.56-0.47$ \\
\hline II/2 (V.B.) & 1961 & 1989 & 15.1 & 16.0 & 43.0 & 43.7 & 74 & 9.1 & 1.3 & 23.2 & 5.9 & $0.62-0.32$ \\
\hline III/1 (V.S.) & 1983 & - & 15.6 & N/A & 40.0 & N/A & 71 & 7.6 & N/A & 18.8 & N/A & $0.58-0.38$ \\
\hline III/2 (M.S.) & 1985 & - & 12.9 & N/A & 33.3 & N/A & 77 & 5.9 & N/A & 31.7 & N/A & $0.52-0.40$ \\
\hline
\end{tabular}

$\mathrm{SE}$, splenectomy. ${ }^{*}$ Normal values of total bilirubin are 3-18 $\mu \mathrm{mol} /$ liter. ${ }^{\ddagger}$ Osmotic fragility is given as an interval between minimum osmotic resistance (normal range $=0.48-0.44$ ) and complete hemolysis (normal $=0.34-0.30$ ) 
$95^{\circ} \mathrm{C}$, and $1 \mathrm{~min}$ at $60^{\circ} \mathrm{C}$ ). This amplification of $\mathrm{cDNA}$ should produce a single band of $106 \mathrm{bp}$ in controls and two bands of $106 \mathrm{bp}$ (representing normal band 3 allele) and 116 bp (representing mutant band 3 allele) in the affected family members. Amplification of genomic DNA with primers P298 and P402 should produce a band of 82 bp in controls and an additional band of $92 \mathrm{bp}$ in the patients.

Hydropathy analysis. Hydrophobicity profiles of the normal and mutant DNA sequences were analyzed and plotted using the computer program SOAP (PCGene; IntelliGenetics, Inc./Betagen, Mountain View, CA). Transmembrane helices were predicted using the programs HELIXMEM and RAOARGOS (PCGene; IntelliGenetics, Inc./ Betagen).

Separation of erythrocytes according to buoyant density. Discontinuous Stractan density gradients were used to separate red blood cells into fractions according to density. Gradients were prepared according to $(29,30) .51 .5-\mathrm{ml}$ solutions of Stractan (Sigma Immunochemicals, St. Louis, MO), with densities of $1.111,1.107,1.094,1.085$, and 1.081 $\mathrm{g} / \mathrm{ml}$, were layered on a cushion of $1.160 \mathrm{~g} / \mathrm{ml}$ density in $15 \mathrm{ml}$ conical tubes (Falcon; Becton Dickinson, Lincoln Park, NJ). $1.5 \mathrm{ml}$ of whole blood was diluted with $4.5 \mathrm{ml}$ PBS and loaded on top of the gradient. Samples were centrifuged at $3,000 \mathrm{~g}$ for $30 \mathrm{~min}$. Cells from the top and bottom interfaces were collected, blood smears were prepared and stained by new methylene blue, and reticulocytes were counted. The blood fractions were washed three times with PBS, the washed cells were lysed with a large excess of $5 \mathrm{mM}$ phosphate buffer, $\mathrm{pH} 7.6$, and red cell membranes were prepared as described (21). Membranes prepared from the top and bottom fractions were electrophoresed in a 3.5-17\% exponential gradient Fairbanks gel and stained with Coomassie blue, and the spectrin to band 3 ratios in the light reticulocyte-rich, and dense reticulocyte-poor fractions were calculated from a densitometric scan of the stained gel.

Extraction of band 3 by octylglucoside. Washed red cells were lysed in 20 vol of $10 \mathrm{mM}$ Tris- $\mathrm{HCl}, \mathrm{pH} 7.4$ (buffer A) and washed three times with buffer $\mathrm{A}$. The ghosts were incubated for $10 \mathrm{~min}$ at $0^{\circ} \mathrm{C}$ with $10 \mathrm{vol}$ of $1 \% \mathrm{~N}$-octylglucoside (Sigma Immunochemicals) diluted in buffer A, centrifuged at $20,000 \mathrm{~g}$ for $15 \mathrm{~min}$ at $4^{\circ} \mathrm{C}$, and the pellets were washed once with buffer A. $30 \mu \mathrm{g}$ of protein were electrophoresed in a $3.5-17 \%$ exponential gradient Fairbanks gel and the Coomassie blue-stained gel was analyzed by densitometry.

Separation of band 3 dimers and oligomers by size-exclusion $H P L C$. Erythrocyte membranes were prepared as described above. The ghosts were solubilized in $5 \mathrm{vol}$ of $0.075 \%$ ( $\mathrm{vol} / \mathrm{vol}$ ) octaethylene glycol- $N$-dodecyl monoether $\left(\mathrm{C}_{12} \mathrm{E}_{8}\right.$; Sigma Immunochemicals $), 5 \mathrm{mM}$ $\mathrm{NaPO}_{4}, 0.2 \mathrm{mM}$ DTT, pH 7.4 (buffer B). The supernatant extracts and ghost residues were separated by centrifugation at $100,000 \mathrm{~g}$ for 30 min at $4^{\circ} \mathrm{C}$. In parallel, spectrin was extracted from the ghosts by incubation with low ionic strength buffer containing $0.1 \mathrm{mM} \mathrm{NaPO}_{4}, 0.1$ mM EDTA, $0.1 \mathrm{mM}$ phenylmethylsulfonyl fluoride and $0.2 \mathrm{mM}$ DTT, pH 8.0 (buffer C). After a 30 -min incubation at $37^{\circ} \mathrm{C}$, spectrin-depleted inside-out vesicles (IOVs) were obtained by centrifugation at $40,000 \mathrm{~g}$ for $30 \mathrm{~min}$, washed once with buffer $\mathrm{C}$, and solubilized in buffer $B$. The supernatant extract and IOV residues were again separated by centrifugation at $100,000 \mathrm{~g}$ for $30 \mathrm{~min}$ at $4^{\circ} \mathrm{C}$. Small-zone size exclusion HPLC was performed at room temperature using a 7.5 $\times 300$-mm TSK SW XL column (TosoHAAS, Philadelphia, PA). Sample volumes of 20-250 $\mu \mathrm{l}$ were injected and a pump (model 510, Waters Instruments, Inc., Rochester, $\mathrm{MN}$ ) was used at a flow rate of 0.5 $\mathrm{ml} / \mathrm{min}$. Protein elution was monitored at $215 \mathrm{~nm}$ using an absorbance detector (Spectroflow 783; Applied Biosystems, Inc., Foster City, CA). The standard elution buffer contained $0.01 \% \mathrm{C}_{12} \mathrm{E}_{8}, 0.1 \mathrm{M}$ $\mathrm{NaCl}$ in $5 \mathrm{mM} \mathrm{NaPO}_{4}, \mathrm{pH} 7.0$.

Lateral and rotational mobility of band 3, glycophorins, and membrane lipids. Lateral and rotational mobility of fluorescently labeled band 3 protein, red cell glycophorins, and membrane lipids were measured in intact washed red cells, as described (31). Briefly, band 3 protein was labeled with E5M, glycophorins were labeled with fluorescein thiosemicarbazide (Molecular Probes), and a fluorescent lipid analog, fluorescein phosphatidylethanolamine (Avanti Polar Lipids, Ala- baster, $\mathrm{AL}$ ), was introduced into the intact red cell membrane as described (31). Lateral mobility of the labeled membrane components was measured by fluorescence photobleaching recovery (31) and rotational mobility of band 3 was measured by polarized fluorescence depletion $(31,32)$.

Sulfate fluxes and DIDS titration curves. Cells were washed three times at $4^{\circ} \mathrm{C}$ in $140 \mathrm{mM} \mathrm{NaCl}$, and $10 \mathrm{mM} \mathrm{Na}$ phosphate, pH 7.4 (PBS), then three times in $84 \mathrm{mM}$ trisodium citrate, $1 \mathrm{mM}$ EGTA, pH 6.5. Washed cells at $20^{\circ} \mathrm{C}$ were subjected to assays of unidirectional disodium $\left[{ }^{35} \mathrm{~S}\right]$ sulfate (ICN Biomedicals, Inc.) uptake in the absence or in the presence of increasing concentrations of the anion transport inhibitor di-isothiocyano-dihydrostilbene disulphonate (DIDS; Molecular Probes) as described (33). Each flux study in HS red cells was performed in parallel using red cells from unrelated healthy subjects. Maximum inhibitory DIDS concentration was calculated by least square linear regression analysis using program Ultra-fit (Biosoft; Elsevier, Ferguson, MO).

Study of intramembrane particle distribution by freeze-fracture electron microscopy. Washed red cells were fixed in $1.75 \%$ glutaraldehyde in $0.1 \mathrm{M}$ sodium cacodylate buffer $\mathrm{pH} 7.4$ for $1.5 \mathrm{~h}$ at $0^{\circ} \mathrm{C}$. The fixed cells were washed five times in $0.05 \mathrm{M}$ sodium cacodylate, $\mathrm{pH} 7.4$, glycerinated ( final glycerol concentration $=33 \%$ ), frozen in freon, and transferred to liquid nitrogen. The samples were fractured in a freezeetch unit (BAF $400 \mathrm{D}$; Balzers, Hudson, $\mathrm{NH}$ ) at $-100^{\circ} \mathrm{C}$. All samples were shadowed at a $45^{\circ}$ angle with platinum-carbon and at a $90^{\circ}$ angle with carbon. Replicas were viewed in a transmission electron microscope (JEM 100S; JEOL U.S.A. Inc., Peabody, MA) at an accelerating voltage of $80 \mathrm{kV}$. Intramembrane particles were quantified in different regions of both patient and control membranes, and the average surface density of intramembrane particles was calculated.

\section{Results}

Protein composition of red blood cell membranes. Analysis of the red blood cell ghosts by SDS-PAGE (Fig. 2) followed by densitometry demonstrated that the ratios of all major skeletal proteins (e.g., spectrin, ankyrin, and protein 4.1 ) to band 3 were proportionately increased, suggesting a $32-39 \%$ deficiency of the band 3 protein (Table II). Immunoblotting with rabbit polyclonal anti-band 3 antibodies did not detect any major immunoreactive bands of abnormal size, except for the normally present minor degradation product of $60 \mathrm{kD}(34)$. The band 3 protein deficiency was directly established by cytofluorometric quantitation of band 3 labeled with eosin-5-maleimide. E5M binds specifically to band 3 protein (25) and its

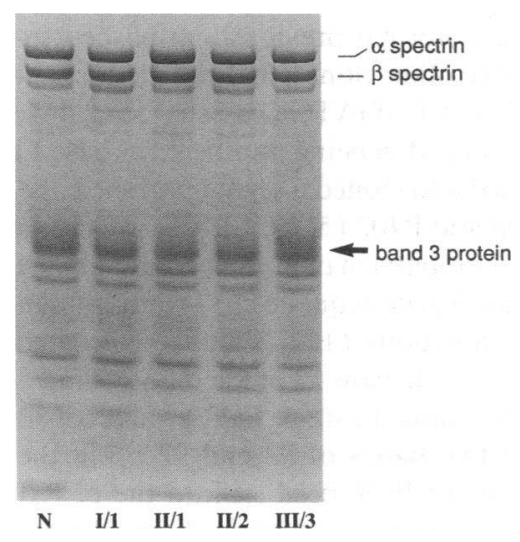

Figure 2. Electrophoresis of solubilized red cell membranes. Red cell membranes were prepared according to ( 21 , 22 ) and $20 \mu \mathrm{g}$ of total membrane protein were solubilized in SDS and electrophoresed in a $3.5-17 \%$ exponential gradient Fairbanks gel $(2,23)$. Results for an unrelated control $\mathrm{N}$, three affected family members I/ 1, II $/ 1$, and II $/ 2$, and the healthy

family member III/ 3 are shown. Densitometric tracings of the gel detected decreased content of band 3 protein relative to spectrin in all three patients shown. 
Table II. Densitometric Quantitation of 3.5-17\% Exponential Gradient Fairbanks Gels, Flow Cytometry Measurements of Relative Band 3 Copy Numbers per Red Cell and Quantitation of Intramembrane Particles in the Affected Family Members

\begin{tabular}{|c|c|c|c|c|c|c|c|c|}
\hline \multirow[b]{2}{*}{ Subject } & \multicolumn{4}{|c|}{ Densitometry of Coomassie blue stained gels } & \multicolumn{2}{|c|}{ Flow cytometry } & \multicolumn{2}{|c|}{ Electron microscopy } \\
\hline & $\begin{array}{l}\text { Spectrin to } \\
\text { band } 3\end{array}$ & $\begin{array}{l}\text { Ankyrin to } \\
\text { band } 3\end{array}$ & $\begin{array}{l}\text { Protein } 4.1 \\
\text { to band } 3\end{array}$ & $\begin{array}{l}\text { Relative band } 3 \\
\text { content }^{*}\end{array}$ & $\begin{array}{l}\text { Fluorescence per } \\
\text { red cell }\end{array}$ & $\begin{array}{l}\text { Relative band } 3 \\
\text { content }^{\ddagger}\end{array}$ & $\begin{array}{l}\text { Intramembrane particle } \\
\text { density }\end{array}$ & $\begin{array}{c}\text { Relative particle } \\
\text { density }\end{array}$ \\
\hline & & & & & arbitrary units & & $I M P / \mu m^{2}$ & \\
\hline Normal range & $0.97 \pm 0.10$ & $0.17 \pm 0.03$ & $0.17 \pm 0.03$ & $100 \%$ & $10.0 \pm 0.7(n=3)$ & $100 \%$ & $3,340 \pm 201(n=10)$ & $100 \%$ \\
\hline I/1 (I.C.) & 1.58 & 0.28 & 0.26 & $61 \%$ & ND & & ND & \\
\hline II/ I (I.F.) & 1.43 & 0.23 & 0.26 & $68 \%$ & ND & & $2,334 \pm 214(n=17)$ & $70 \%$ \\
\hline II/2 (V.B.) & 1.50 & 0.20 & 0.23 & $65 \%$ & $5.9 \pm 0.6(n=2)$ & $59 \%$ & ND & \\
\hline III/1 (V.S.) & 1.50 & 0.23 & 0.21 & $65 \%$ & $5.5 \pm 0.6(n=2)$ & $55 \%$ & $2,607 \pm 209(n=20)$ & $78 \%$ \\
\hline III/2 (M.S.) & 1.43 & 0.25 & 0.21 & $68 \%$ & $5.6(n=1)$ & $56 \%$ & $2,324 \pm 91(n=10)$ & $70 \%$ \\
\hline
\end{tabular}

Average values are means \pm SD. $n$, number of determinations. ${ }^{*}$ Relative band 3 content as calculated from the spectrin to band 3 ratio. ${ }^{\ddagger}$ Relative to the control samples.

single cell fluorescence intensity, measured by flow cytometry, is therefore directly proportional to the number of band 3 molecules in each cell. While the average fluorescence intensity of normal red cells was normalized to $10.0 \pm 0.7$ arbitrary units per red cell, the fluorescence intensity of red cells from the affected family members ranged from $5.5 \pm 0.6$ to $5.9 \pm 0.6$ arbitrary units per red cell, demonstrating an average $41-45 \%$ decrease in the number of band 3 molecules per red cell (Table II).

Screening of band 3 cDNA for SSCP. We screened the coding region of band 3 cDNA from affected family members for $\operatorname{SSCP}(27,28)$ in overlapping cDNA segments of 300-400 bp. We detected an abnormal SSCP pattern characterized by the presence of two normally migrating and two slower migrating bands (not shown) in a cDNA segment of $314 \mathrm{bp}$ from nt 2,423 to nt 2,736 (PCR primers P356 (5'-GCATCTTGCTTCTGTTCAAGCCA-3') and P165(5'-TCACACAGGCATGGCCACTTC)) that codes for the $\mathrm{COOH}$-terminal 103 amino acids of band 3 protein.

Sequence analysis of band $3 c D N A$ and genomic DNA. A 482-bp segment of patient cDNA was amplified using primers P298 and P195 and cloned into vector pCRII. 24 clones containing the PCR-amplified cDNA were prepared, pooled and sequenced on both strands using the Sequenase Version 2.0 DNA Sequencing Kit (United States Biochemical Corp.). Since sequencing of the pooled clones indicated the presence of a 10 nucleotide insertion, six clones were sequenced individually. Three clones yielded a normal previously published sequence $(35,36)$. In the three other clones, we found a duplication of a decanucleotide CACCCAGATG (bases 2,455-2,464, the first base of the initiation codon being numbered as base 1) (Fig. 3). We PCR-amplified and cloned a segment of the band 3 gene using primers P298 and P402 (5'-CCGCTTGACGTAGGGCACAT $-3^{\prime}$ ) that, by comparison of human band 3 cDNA sequence with mouse band 3 gene sequence (37) and human band 3 gene exon-exon junctions (16), should be located within an exon homologous with exon 18 of the mouse band 3 gene. Correspondingly, we obtained a single PCR product of 82 bases in the controls and two bands of 82 and $92 \mathrm{bp}$ in the patient. We cloned the patient PCR product into the pCRII vector and sequenced seven clones as described above. We detected the 10 nucleotide insertion in four clones and a normal sequence in three clones. Based on the city of origin of the kindred, we designated this abnormal allele Band 3 Prague.
Structural consequences of the frameshift insertion. The 10base insertion introduces a frameshift into the coding sequence of band 3 and is predicted to create an altered $\mathrm{COOH}$ terminus of band 3. Since the insertion occurs 90 codons upstream from the normal stop codon, the $\mathrm{COOH}$-terminal 90 amino acids of the normal band 3 protein are predicted to be replaced by an abnormal sequence of 70 amino acids. The predicted molecular weight of the mutant protein is $98.4 \mathrm{kD}$, compared with $101.7 \mathrm{kD}$ for normal band 3. We calculated and plotted the hydropathy profile of the normal and mutant band 3 proteins using the computer program SOAP (Fig. $4 A$ ). The mutant protein lacks the $\mathrm{COOH}$-terminal hydrophobic stretch of amino acids present in the normal protein; this sequence is replaced by a slightly polar $\mathrm{COOH}$ terminus. The programs HELIXMEM and RAOARGOS predict that the mutant $\mathrm{COOH}$ terminus cannot form a transmembrane segment. Therefore, if the mutant allele is translated and the mutant

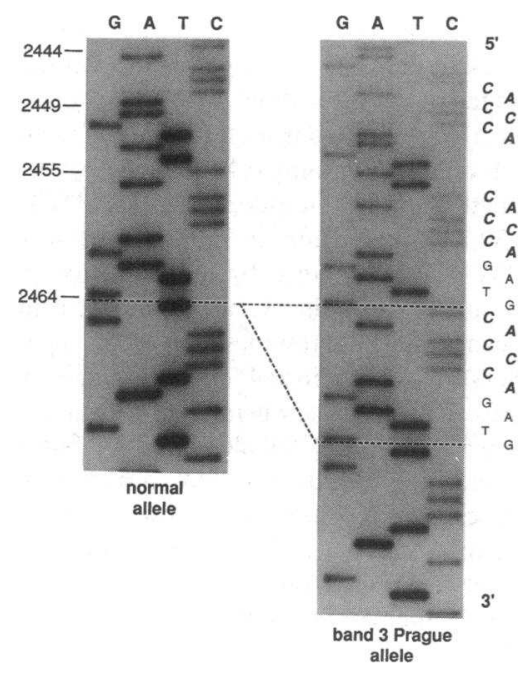

Figure 3. Frameshift insertion in one band 3 allele. A 482-bp segment of patient cDNA was amplified using primers P298 and P195, cloned into vector pCRII and 24 clones containing the PCRamplified cDNA were pooled and sequenced. Since sequencing of the pooled clones indicated the presence of a 10-nucleotide insertion, six clones were sequenced individually. Three clones yielded a normal previously published sequence $(35,36$ ) (left

panel). In the three other clones, corresponding to the other band 3 allele, we found a duplication of a decanucleotide CACCCAGATG (bases $2,455-2,464$, the first base of the initiation codon being numbered as base 1 ). The duplicated sequence is preceded in the normal sequence by a direct repeat CACCCA (bases 2,444-2,449, highlighted) that is identical to the first six bases of the duplicated sequence. 
A

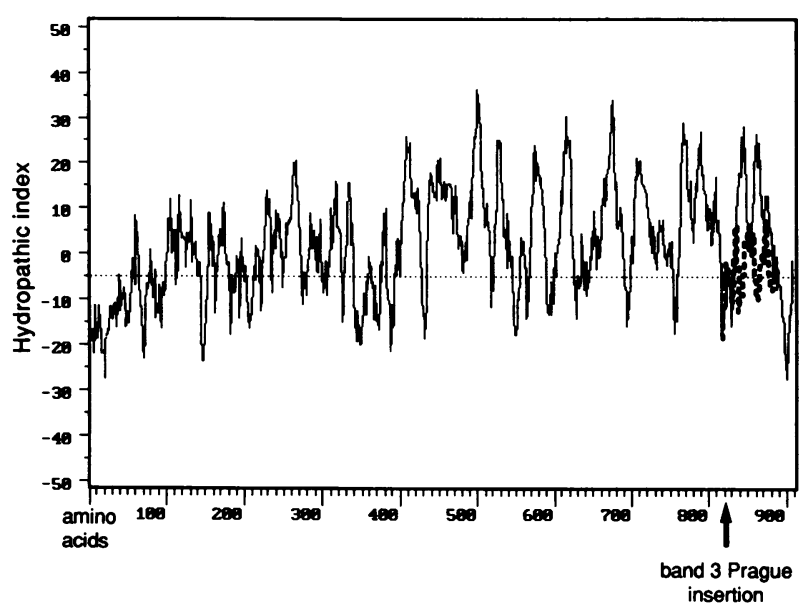

B

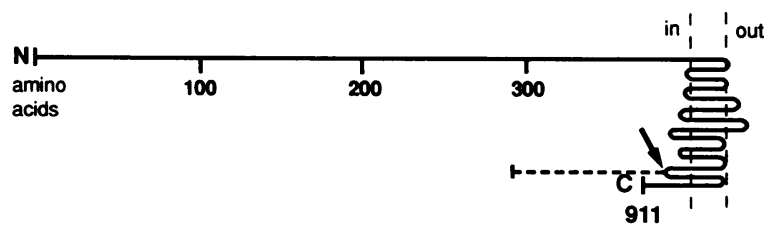

Figure 4. Hydropathy analysis and prediction of transmembrane helices. $(A)$ The hydropathic indices of the normal and mutant band 3 proteins were calculated and plotted using the program SOAP. The frameshift insertion replaces the long terminal hydrophobic stretch of amino acids (solid line) by a truncated slightly polar $\mathrm{COOH}$ terminus (dashed line). The position of the insertion is marked by an arrow. (B) 14 transmembrane segments are shown for the normal band 3 protein according to $(36)$, although the topology and number of the last few $\mathrm{COOH}$-terminal transmembrane segments are not precisely known. The number and position of the transmembrane segments for the mutant protein were based on the reported amino acid sequence $(35,36)$ and were predicted using the programs RAOARGOS and HELIXMEM (PCGene). According to these predictions, the new $\mathrm{COOH}$ terminus cannot form a transmembrane segment. Therefore, if the mutant protein were cotranslationally inserted into the membrane, $\sim 105 \mathrm{COOH}$-terminal amino acids would protrude from the membrane, most likely at its cytoplasmic face. The position of the Band 3 Prague insertion is marked by an arrow.

band 3 protein is cotranslationally inserted into the membrane, we would expect that a much longer hydrophilic $\mathrm{COOH}$ terminus protrudes from the cytoplasmic face of the membrane ( 105 amino acids instead of the 30 amino acids in the normal band 3, as predicted by Lux et al. [36]). Fig. $4 B$ shows schematically the position of the band 3 Prague mutation in the band 3 molecule. The dashed line denotes the protruding mutant $\mathrm{COOH}$ terminus.

Coinheritance of the 10-base duplication and the band 3-deficient HS phenotype. The presence of the insertion was verified in all five affected family members by PCR amplification of reverse transcribed total reticulocyte RNA using primers P298 and P243 that flank the insertion site. This amplification produced a single band of $106 \mathrm{bp}$ in the unaffected family member III/ 3 and in unrelated controls, and two bands of 106 and 116 bp in the affected family members (Fig. $5 \mathrm{~A}$ ). Genomic DNA from all affected family members and controls was PCR amplified using primers P298 and P402, which produced a single
A

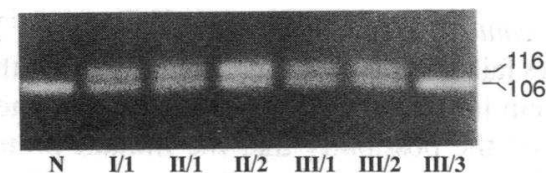

B

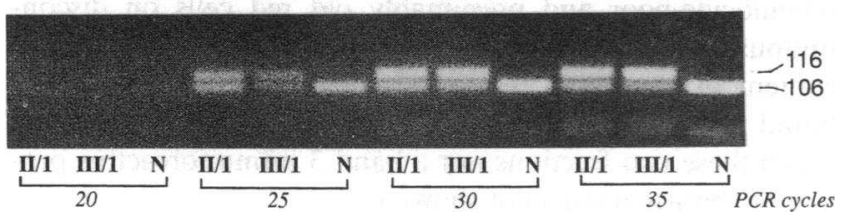

Figure 5. Coinheritance of the 10-nucleotide insertion and spherocytosis. Similar amounts of mRNA are detected for both normal and mutant band 3 alleles. $(A)$ The presence of the insertion was verified in all five affected family members by PCR amplification of reversetranscribed total reticulocyte RNA using primers P298 and P243 flanking the insertion. This amplification produces a single band of $106 \mathrm{bp}$ in controls and two bands of 106 and $116 \mathrm{bp}$ in the affected family members. The insertion was found in all five affected family members demonstrating coinheritance of the band 3 mutation and the spherocytosis phenotype. The insertion was not detected in the healthy family member III/ 3 and an unrelated control N. $(B)$ The amount of mRNA corresponding to the Band 3 Prague allele was compared to the quantity of mRNA encoding the normal band 3 allele. Band 3 cDNA from two patients and a control subject was PCR amplified using primers $\mathrm{P} 298$ and $\mathrm{P} 243$. Aliquots of the $\mathrm{PCR}$ reaction after $15,20,25,30$, and 35 cycles were electrophoresed in a $4 \%$ agarose gel. After 25 cycles of PCR, the intensities of bands corresponding to the individual alleles are identical, suggesting that equal amounts of normal and mutant mRNA are present in patient reticulocytes. After $\geq 30$ PCR cycles the intensity and width of the 116-bp band increases, very likely due to the formation of heteroduplexes.

PCR product of $82 \mathrm{bp}$ in the controls and two bands of 82 and 92 bp in all five affected family members (not shown).

Expression of the mutant protein. PCR amplification with primers P298 and P243 and lower numbers of PCR cycles produced bands of similar intensities, suggesting the presence of equal amounts of mRNA for each band 3 allele. To verify this conclusion, we followed the relative intensities of both PCR bands as the number of PCR cycles was increased. Equal intensities of the two PCR bands were obtained for $\leq 25$ PCR cycles (Fig. $5 \mathrm{~B}$ ), suggesting again that mRNA corresponding to both alleles of band 3 is present in equal amounts. After higher number of cycles, the intensity of the longer band became higher than that of the normal PCR product, very likely caused by the formation of heteroduplexes.

Since equal levels of mRNAs for both band 3 alleles are present, the mutant mRNA should be translated into a mutant band 3 protein. If the mutant protein were cotranslationally inserted into the membranes of the endoplasmic reticulum and then properly translocated to the plasma membrane, a shorter additional band should be seen on SDS-PAGE of band 3 Prague red cell membrane proteins. However, no differences in the apparent molecular weight of band 3 protein were seen both on Coomassie blue-stained Fairbanks gels (Fig. 2) and Laemmli gels (not shown). In addition, immunoblots of these gels with polyclonal anti-band 3 antibodies did not demonstrate any immunoreactive bands of abnormal size (not shown), suggesting that the mutant protein is not present in the membrane of mature erythrocytes. 
Band 3 content of density-separated red cells. Since the above studies failed to demonstrate the presence of the mutant band 3 protein in the total population of red cell membranes, we considered the possibility that the mutant protein is lost from the cells during their circulation in vivo. Therefore, we separated the light reticulocyte-rich red cells from the dense reticulocyte-poor and presumably old red cells on discontinuous Stractan density gradients and measured the relative content of band 3 in the two fractions by SDS-PAGE. We found neither a significant difference in band 3 content between these two fractions nor a band 3 immunoreactive protein of abnormal size (not shown).

Therefore, we conclude that band 3 is not lost from the cells after their release into the circulation. Additional evidence against the loss of band 3 protein in the circulation was obtained by cytofluorometric quantitation, which detected a small standard deviation of fluorescence intensity both in the patient erythrocytes, as well as in the normal red blood cells (Table II). Significant loss of band 3 protein would be expected to produce a significantly larger standard deviation of fluorescence intensity in the patient cells than in control erythrocytes.

Analysis of the oligomeric states of band 3 in the membrane and the association of band 3 with the skeleton. Band 3 protein is principally present in the normal red cell membrane in the form of dimers, tetramers, and higher order oligomers (38). The latter two species are thought to be associated with the membrane skeleton. To establish whether the deficiency of band 3 protein affected the self-association of band 3 or the interactions of band 3 with the underlying skeleton, we first measured the retention of band 3 protein in the membrane skeleton using octylglucoside extraction of membranes. Second, we analyzed the oligomeric state of band 3 by size exclusion HPLC of $\mathrm{C}_{12} \mathrm{E}_{8}$ extracts from membranes and IOV.

First, we treated patient and normal membranes with a mild detergent, octylglucoside, that selectively extracts only those integral proteins that are not anchored tightly to the membrane skeleton (39). The same amount of band 3 protein was retained in the patient and normal skeletons. In a striking contrast, considerably less band 3 protein was released from the membranes of the HS subjects than from the control membranes (Table III), suggesting that the band 3 deficiency pri-

Table III. Octylglucoside Extraction of Band 3 from Patient and Control Red Cell Membranes

\begin{tabular}{lccc}
\hline & \multicolumn{2}{c}{ Spectrin/band 3 ratio } & \\
\cline { 2 - 3 } \multicolumn{1}{c}{ Subject } & Before extraction & After extraction & $\begin{array}{c}\text { Band 3 extracted } \\
(\%)\end{array}$ \\
\hline II/1 & 1.58 & 2.60 & 39 \\
II/2 & 1.41 & 2.70 & 48 \\
III/1 & 1.50 & 2.64 & 43 \\
III/2 & 1.43 & 2.90 & 51 \\
Average patients & $1.48 \pm 0.11$ & $2.71 \pm 0.21$ & $45 \pm 8$ \\
Control 1 & 1.02 & 2.80 & 64 \\
Control 2 & 1.01 & 2.40 & 58 \\
Control 3 & 0.98 & 2.60 & 62 \\
Control 4 & 1.01 & 2.95 & 66 \\
Average controls & $1.01 \pm 0.01$ & $2.69 \pm 0.11$ & $65 \pm 2$ \\
& & & \\
\hline
\end{tabular}

Average values are means \pm SD. marily involves the extractable fraction of band 3 that is not tightly bound to the skeleton.

To examine the self-association of band 3 in patient and normal membranes, we used size-exclusion HPLC. First, we measured the amount of band 3 dimers extracted by the mild nonionic detergent $\mathrm{C}_{12} \mathrm{E}_{8}$ from equal numbers of patient and control membranes. $\mathrm{C}_{12} \mathrm{E}_{8}$ extracted $38-45 \%$ less band 3 dimers from patient than from control membranes, suggesting a deficiency of the dimeric fraction of band 3 in membranes from the affected individuals (not shown). Second, we measured the relative amounts of band 3 dimers and higher oligomers of band 3 in $\mathrm{C}_{12} \mathrm{E}_{8}$-extracted spectrin-depleted IOV. The band 3 species in individual peaks were identified by comparing the HPLC profile with a profile of purified band 3 protein. The other major transmembrane proteins, glycophorins, commigrated with the $\mathrm{C}_{12} \mathrm{E}_{8}$ peak. Protein analysis of individual peaks revealed the presence of protein 4.2 in both band 3 peaks and a small amount of ankyrin in the peak of band 3 tetramers and higher complexes. Fig. 6 shows a typical result of 10 independent experiments demonstrating a smaller band 3 dimer/ band 3 tetramer ratio in the patient compared to the control sample, further supporting the conclusion that the deficiency of the band 3 occurs at the expense of the dimeric band 3 fraction.

Lateral and rotational mobility of band 3 protein. Previous studies of lateral and rotational mobility of band 3 protein in the normal red cell membrane have revealed the presence of several distinct band 3 fractions. In terms of lateral mobility, two principal fractions have been identified: $(a)$ an immobile fraction that most likely represents ankyrin-linked band 3 tetramers and higher order oligomers; and $(b)$ a mobile fraction that most likely represents band 3 species that are not directly associated with the membrane skeleton and can, therefore, migrate laterally over $\mu \mathrm{m}$-scale distances in the plane of the lipid bilayer $(31,40)$. Rotational mobility studies have previously identi-

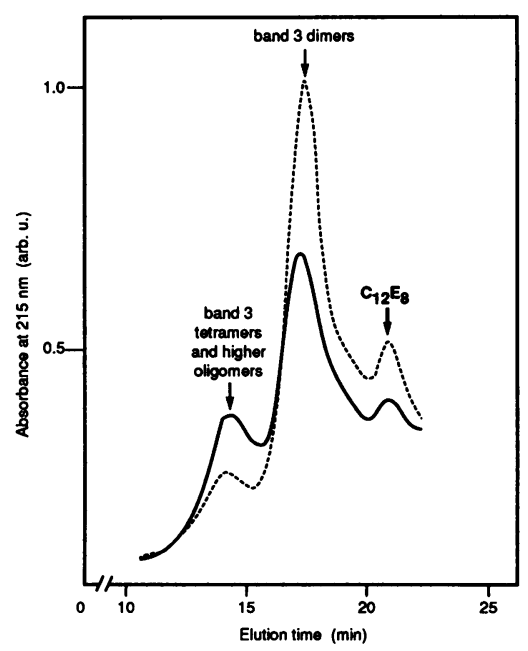

Figure 6. Analysis of ankyrin/band 3 complexes in spectrinstripped inside-out vesicles. Size exclusion HPLC of band 3-ankyrin-protein 4.2 complexes extracted by $\mathrm{C}_{12} \mathrm{E}_{8}$ from spectrin-depleted inside-out-vesicles demonstrates a decrease in the ratio of band 3 dimer peak to the peak that includes band 3 tetramers and higher oligomers in a carrier of the Band 3 Prague mutation (solid line). The band 3 species were identified by comparing the HPLC profile with a profile of purified band 3 protein. Protein analysis of individual peaks revealed the presence of protein 4.2 in both band 3 peaks and a small amount of ankyrin in the peak of band 3 tetramers and higher complexes. A typical result of 10 independent experiments in four affected family members and matched controls is shown. Control curve is dashed. 
Table IV. Lateral Mobility of band 3, Glycophorins, and Lipids, and Rotational Mobility of Band 3 in Patient and Control Membranes

\begin{tabular}{|c|c|c|c|c|c|c|c|c|c|c|c|}
\hline \multirow[b]{2}{*}{$\begin{array}{l}\text { Mobility } \\
\text { Parameter }\end{array}$} & \multicolumn{5}{|c|}{ Rotational } & \multicolumn{6}{|c|}{ Lateral } \\
\hline & $\alpha(\%)$ & $\tau_{1}$ & $\beta(\%)$ & $\tau_{2}$ & $\begin{array}{c}\text { Immobile } \\
\text { component (\%) }\end{array}$ & D/band 3 & $\begin{array}{c}\text { F/band } 3 \\
(\%)\end{array}$ & D/glycophorins & $\begin{array}{c}\text { F/glycophorins } \\
(\%)\end{array}$ & D/lipids & $\begin{array}{c}\text { F/lipids } \\
(\%)\end{array}$ \\
\hline & & $\mu S$ & & $m s$ & & $10^{-11} \mathrm{~cm}^{2} \mathrm{~s}^{-1}$ & & $10^{-11} \mathrm{~cm}^{2} \mathrm{~s}^{-1}$ & & $10^{-11} \mathrm{~cm}^{2} \mathrm{~s}^{-1}$ & \\
\hline II/1 & - $^{*}$ & - $^{*}$ & 83 & 2.53 & 17 & $-^{\ddagger}$ & $<10$ & ND & ND & ND & ND \\
\hline $\mathrm{II} / 2$ & -* & - $^{*}$ & 84 & 1.08 & 16 & - $^{\ddagger}$ & $<7$ & $2.9 \pm 0.8$ & $43 \pm 13$ & $237 \pm 69$ & $94 \pm 5$ \\
\hline III/2 & $-^{*}$ & $-^{*}$ & 60 & 0.58 & 40 & $\ldots^{\ddagger}$ & $<9$ & $2.3 \pm 0.5$ & $48 \pm 18$ & $251 \pm 133$ & $93 \pm 5$ \\
\hline $\begin{array}{c}\text { Average for } \\
\text { patients }\end{array}$ & $-^{*}$ & - $^{*}$ & $76 \pm 14$ & $1.40 \pm 1.00$ & $24 \pm 14$ & - $^{\ddagger}$ & $<10$ & $2.6 \pm 0.6$ & $46 \pm 16$ & $244 \pm 101$ & $94 \pm 5$ \\
\hline Control & 32 & $<50$ & 51 & 0.94 & 17 & $2.2 \pm 1.0$ & $49 \pm 5$ & $2.2 \pm 0.8$ & $47 \pm 13$ & $172 \pm 79$ & $94 \pm 8$ \\
\hline
\end{tabular}

$\alpha$, rapidly rotating fraction of band $3 ; \tau_{1}$, rotational correlation time for the rapidly rotating band 3 molecules; $\beta$, slowly rotating fraction of band $3 ; \tau_{2}$, rotational correlation time for the slowly rotating band 3 molecules; $\mathrm{D}$, lateral diffusion coefficient; $\mathrm{F}$, laterally mobile fraction. ${ }^{*} \mathrm{Rap}-$ idly rotating component of band 3 was not observed in the patient samples. ${ }^{\ddagger} \mathrm{D}$ cannot be reliably measured for $\mathrm{F}<20 \%$. Average values are means \pm SD. ND, not determined.

fied three band 3 populations: $(a)$ a rotationally immobile fraction of band 3 molecules thought to comprise proteins bound directly to ankyrin; $(b)$ a slowly rotating population believed to represent band 3 oligomers that are either bound indirectly to ankyrin or present as larger aggregates in the membrane; and (c) a rapidly rotating fraction consisting of band 3 species (primary dimeric and tetrameric) that rotate freely in the lipid bilayer $(31,41)$. Thus, studies of band 3 lateral and rotational mobility in our HS kindred could provide an assessment of band 3 self-association and of the interaction of band 3 with the skeleton in the intact membrane, and thereby complement our results from the HPLC studies of the oligomeric species of band 3 described above. We used fluorescence photobleaching recovery to measure band 3 lateral mobility and polarized fluorescence depletion to measure band 3 rotational mobility in intact patient and control red cells. Compared to results in the control cells, there was a marked decrease in the laterally mobile fraction of band 3 in red cells from all three HS family members studied (Table IV). In contrast, the lateral mobility of glycophorins and membrane lipids was normal. The rapidly rotating component of band 3 molecules was absent in the patient membranes, although slowly rotating and rotationally immobile forms were present (Table IV). Thus, these results are consistent with the extraction data, suggesting that the "free" fraction of band 3 (i.e., the molecules not associated either

Table V. Band 3-mediated, DIDS-inhibitable ${ }^{35} \mathrm{SO}_{4}$ Fluxes

\begin{tabular}{lcc}
\hline Patient & $\begin{array}{c}{ }^{35} \mathrm{SO}_{4} \text { flux } \\
\text { (\% control) }^{*}\end{array}$ & $\begin{array}{c}\text { DIDS inhibitory concentration } \\
\text { (\% control) }\end{array}$ \\
\hline II/1 & 38.2 & 69 \\
II/2 & 46.1 & 70 \\
III/1 & 54.9 & 58 \\
III/2 & 72.9 & 48 \\
Average $^{\ddagger}$ & $53 \pm 15$ & $61 \pm 10$ \\
\hline
\end{tabular}

* Fluxes are means of at least three triplicate samples. For each measurement, a matched control was measured in parallel and the rate of sulfate flux and DIDS inhibitory concentrations were expressed as percent of control values. ${ }^{\ddagger}$ Average values are means \pm SD. directly or indirectly with the underlying skeleton) is selectively depleted in intact patient membranes.

Anion transport. Since band 3 is the principal anion exchange protein of the red cell membrane (16), we compared anion fluxes in band 3-deficient HS and in normal red cells. We found that the $32-39 \%$ decrease in relative band 3 content by gel densitometry and $41-45 \%$ decrease by flow cytometry was reflected by a proportional, $47 \pm 15 \%$ decrease in the DIDSsensitive influx of radiolabeled sulfate that serves as a measure of the transport function of band 3 (42) (Table V). In addition, proportionately lower concentrations of the anion transport inhibitor DIDS were needed for maximal inhibition of sulfate influx (Fig. 7). Both the decrease in sulfate influx and the decrease in the maximally effective DIDS concentration were proportional to the degree of band 3 deficiency.

Distribution of intramembrane particles visualized by freeze-fracture electron microscopy. Since band 3 is the major component of intramembrane particles $(43,44)$, we measured the size and number of these particles. Fig. 8 compares the low angle shadowed outer face of the inner leaflet of the lipid bilayer (P-face) of patient and control membranes. Quantitation of intramembrane particles in 10 different electron micrographs from each subject revealed a $22-30 \%$ decrease in particle density in the patient membranes (Table II).

\section{Discussion}

We describe a kindred with autosomal dominant hereditary spherocytosis and band 3 protein deficiency in which a duplication of 10 bases in the coding region of one band 3 allele was coinherited with the HS phenotype. Because of the ensuing shift of the reading frame, the mutant allele encodes a truncated band 3 protein that is predicted to have an abnormal $\mathrm{COOH}$ terminus of 70 amino acids replacing the normal 90 amino acid $\mathrm{COOH}$-terminal sequence. The decanucleotide insertion was detected initially in cDNA from affected individuals and subsequently found within exon 18 of the human band 3 gene $(16,37)$. The first six bases of the duplicated decanucleotide, CACCCA, are a direct repeat of a hexanucleotide sequence located 11 bases upstream in the normal sequence, suggesting that the most likely mechanism leading to 


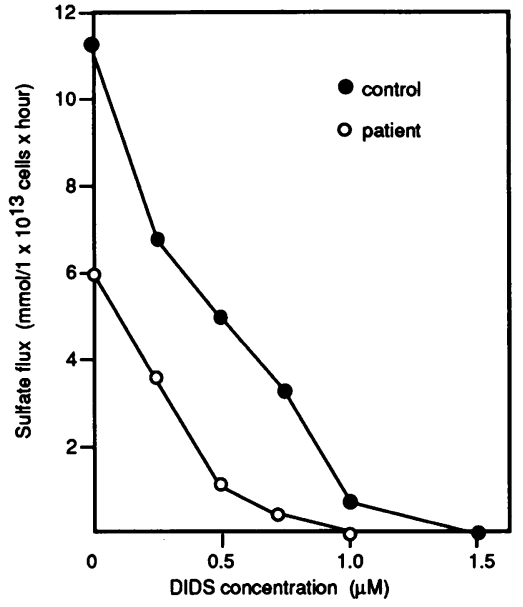

sites. The two slopes, reflecting the affinity of the DIDS-band 3 interaction, are not significantly different in patient and control erythrocytes. Each point represents the mean of triplicate determinations, with standard deviations of $<15 \%$ of mean.

the duplication was a slipped mispairing during replication (45).

Two independent techniques of band 3 quantitation (i.e., measurement of spectrin to band 3 ratios by gel densitometry and the cytofluorometric quantitation of band 3 protein in single cells) revealed similar degrees of band 3 deficiency, although in flow cytometry measurement the decrease in band 3 content was slightly more pronounced: $41-45 \%$ deficiency by flow cytometry vs $32-39 \%$ deficiency by SDS-PAGE. This difference could be caused by either different sensitivities of the two approaches or a mild accompanying deficiency of spectrin and other skeletal proteins, resulting in a minor underestimation of the absolute band 3 deficiency by relative quantitation from gel densitometry. Quantitation of intramembrane particles visualized by freeze-fracture electron microscopy, the principle component of which is thought to be band 3 , also reveals an $18-30 \%$ decrease in particle density in patient membranes, in good agreement with the two other methods of band 3 quantitation. Band 3 protein deficiency in patient red cells was likewise accompanied by a proportional decrease in DIDS-inhibitable sulfate flux ( Table V).

Our data strongly suggest that the deficiency of band 3 protein occurs primarily at the expense of the dimeric fraction of band 3 that is not associated with the membrane skeleton. The experimental results supporting this conclusion are as follows: (a) The mild detergent octylglucoside, which extracts only the fraction of band 3 that is not bound to the skeleton (39), releases considerably less band 3 from patient membranes than from normal membranes. In contrast, the postextraction ratio of spectrin to band 3 (i.e., the fraction of band 3 retained by the skeletons) is the same in normal and mutant red cells (Table II). (b) Consistent with these data, there is a relative decrease in the amount of band 3 dimer as measured by size-exclusion HPLC, whereas the amount of higher order band 3 oligomers (including tetramers) is unchanged (Fig. 6). (c) The laterally mobile fraction of band 3 , which presumably represents the fraction of band 3 that is not bound to the membrane skeleton, is likewise significantly decreased in patient red cells (Table IV). (d) The rapidly rotating fraction of band 3, which likely represents freely mobile band 3 dimers and tetramers, is absent in patient red cells ( Table IV).

The difference between the rapidly rotating fraction of band 3 (presumably representing band 3 dimers and nondetectable in our experiments) and the percentage of band 3 dimers
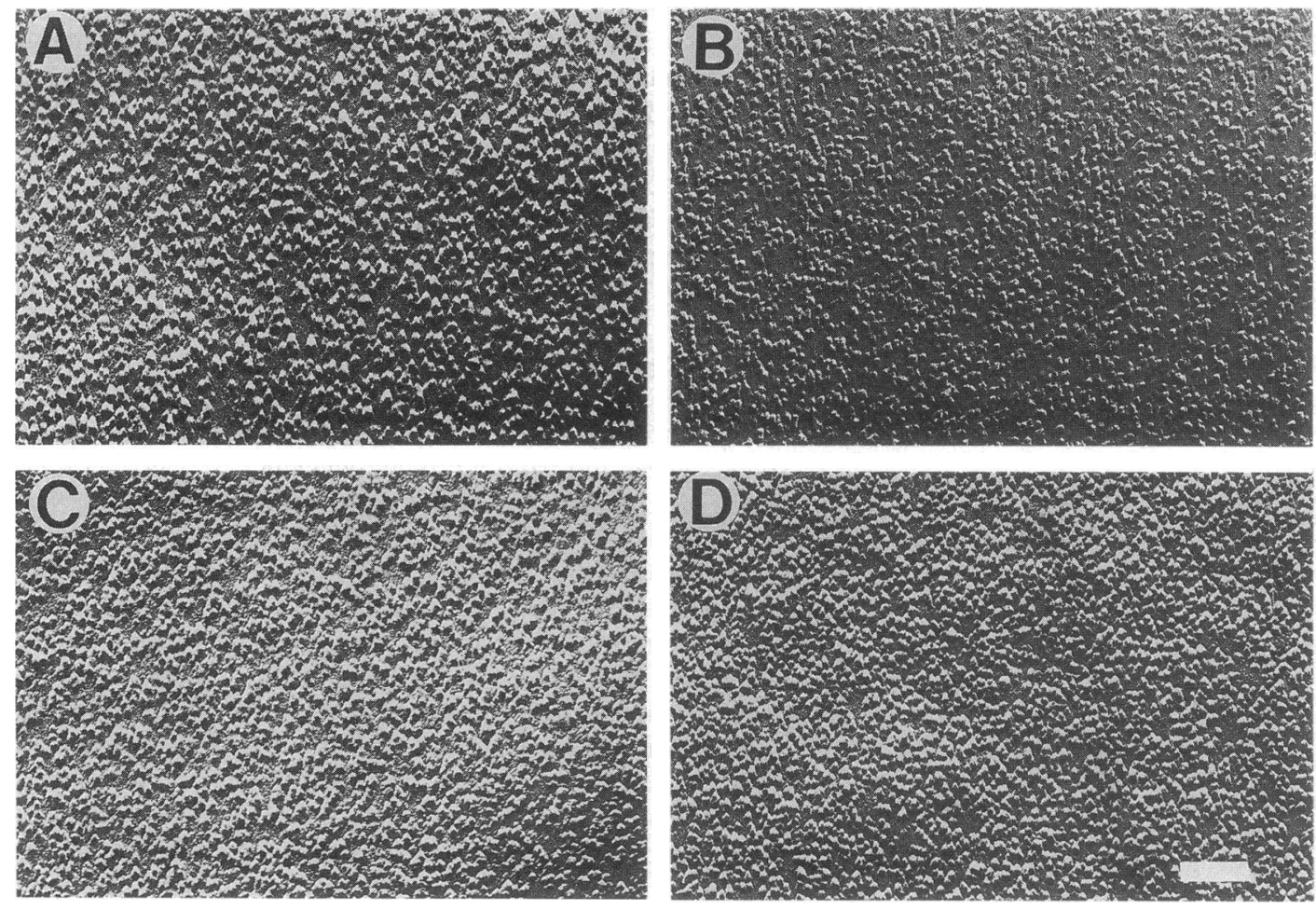

Figure 8. Freeze-fracture electron microscopy. The outer face of the inner leaflet of the membrane bilayer ( $P$ face) is shown for membranes of patients II $/ 1(A), \mathrm{II} / 2(B)$, and III/1 $(C)$, as well as control $(D)$ membranes. Quantitation of intramembrane particles in 10 different electron micrographs from each of the three patients and a control subject reveals an average decrease of $22-30 \%$ in the surface density of particles in patient membranes (see also Table II). The white bar corresponds to $100 \mathrm{~nm}$. 
measured by size-exclusion HPLC may be caused by the fact that $(a)$ the fraction of the rapidly rotating band 3 dimers is below the detection limits of the technique or $(b)$ some of the band 3 dimers in the extracts used for the HPLC study may originate from band 3 tetramers that dissociated into dimers during preparation of the extract. Although the data are not quantitatively the same, they are qualitatively identical, pointing out that the band 3 deficiency leads to a decrease in the dimeric fraction of band 3 .

We found equal amounts of mRNA for both mutant and normal band 3 alleles in the affected family members, suggesting that the insertion does not lead to preferential transcription or processing of one of the band 3 alleles (Fig. 5). At the same time, we did not detect the mutant protein in the mature red cell membrane. The mechanism leading to band 3 deficiency in red cell membranes of affected individuals is unknown. We propose the following hypothetical possibilities: (a) abnormal translocation of mutant band 3 from the endoplasmic reticulum to the plasma membrane, $(b)$ decreased cotranslational insertion of band 3 into membranes of the endoplasmic reticulum, $(c)$ a rapid degradation of the mutant protein in the membrane of bone marrow erythroblasts, or $(d)$ loss from the cells during enucleation which is preceded by a marked reorganization of the erythroblast plasma membrane (46). With regard to the first hypothetical mechanism of band 3 deficiency, it is important to also consider a possibility of altered interaction of mutant band 3 protein with glycophorin A, since recent studies of Tanner and co-workers indicate that glycophorin A may help ferry band 3 from the endoplasmic reticulum to the plasma membrane (47). The second possibility is probably the least likely, since internal signal sequence either precedes or is coincident with the first membrane spanning segment (48). On the other hand, our data exclude a possibility that the band 3 deficiency is a consequence of a progressive loss of band 3 from the plasma membrane during the circulation or red blood cells in vivo. Evidence for this conclusion includes the absence of differences in band 3 content between the light reticulocyterich, and dense presumably old, red cell fractions isolated on Stractan density gradients. In addition, the number of eosin maleimide labeled band 3 molecules per red cell is similar for most cells, since the standard deviation of single cell fluorescence intensity is low as measured by flow cytometry. If band 3 protein were lost progressively from circulating red cells, much wider distribution of erythrocyte band 3 content would be expected.

Using freeze-fracture electron microscopy, we detected a decrease in the surface density of intramembrane particles in patient red cells (Fig. 8). Band 3 protein, together with other integral membrane proteins is thought to stabilize the membrane by interacting with adjacent (boundary) lipid molecules (49). A decrease in the content of band 3 could lead to formation of protein-free areas of the lipid bilayer lacking the stabilizing protein-lipid and protein-protein interactions, as was proposed by Lux and co-workers on the basis of radioimmunoassay and SDS-PAGE analysis of spectrin, ankyrin and band 3 content in red cell membranes (13). Such areas of the membrane might be unstable and abnormally susceptible to release from the membrane. We propose that a release of such membrane material likely represents the mechanism leading to surface area deficiency and spherocytosis in red cells from the studied family. Such a hypothesis is supported by earlier stud- ies revealing that clustering of intramembrane particles in ghosts is followed by a formation of particle-free blebs, which are the sites of lipid loss from the membrane via microvesicle formation (50).

In conclusion, we report a heritable frameshift insertion of 10 nucleotides in the band 3 gene that represents the first reported band 3 mutation associated with spherocytosis and a partial deficiency of the band 3 protein. The band 3 deficiency is further reflected by a decrease in the rate of transmembrane sulfate flux and a decrease in the number of DIDS-inhibitable sulfate transporters. Since we did not detect the mutant protein in the membrane, we suggest that the likely mechanism leading to band 3 deficiency is the inability of the protein product of the mutant allele to be cither stably inserted into the endoplasmic reticulum membrane or properly translocated to the plasma membrane, or that it is lost from the erythroblast membrane before the release of red cells into the circulation. We demonstrate that the band 3 deficiency principally involves a decrease in the dimeric fraction of the band 3 protein, which is both laterally and rotationally mobile and presumably not bound to the membrane skeleton in control red cells. Lastly, the finding of a decreased density of intramembrane particles leads us to propose that the surface area deficiency and spherocytosis in affected red cells may be caused by the release of lipid vesicles at the sites of intramembrane particle-free areas of the lipid bilayer.

\section{Acknowledgments}

We thank Ms. Donna-Marie Mironchuk for preparation of the figures.

This work was supported by National Institutes of Health grants HL-37462 and HL-27215 (to J. Palek), HL-32854 and HL-15157 (to D. E. Golan), DK-43495 (to S. Alper), and HL-15157 (to C. Brugnara).

\section{References}

1. Palek, J., and P. Jarolim. 1993. Clinical expression and laboratory detection of red cell membrane protein mutations. Semin. Hematol. 30:249-283.

2. Agre, P., J. F. Casella, W. H. Zinkham, C. McMillan, and V. Bennett. 1985. Partial deficiency of erythrocyte spectrin in hereditary spherocytosis. Nature (Lond.). 314:380-383.

3. Jarolim, P., V. Brabec, S. K. Ballas, J. T. Prchal, M. Poon, R. Castleberry, D. Arnold, T. L. Coetzer, S. Li:l, and J. Palek. 1992. Biochemical heterogeneity of the hereditary spherocytosis syndrome. Abstr. 24th Congr. Int. Soc. Haematol. 35. (Abstr.)

4. Savvides, P., O. Shalev, K. M. John, and S. E. Lux. 1991. Combined spectrin and ankyrin deficiency is common in autosomal dominant hereditary spherocytosis. Clin. Res. 39:313A. (Abstr.)

5. Marchesi, S. L., P. Agre, D. W. Speicher, W. T. Tse, and B. G. Forget. 1989. Mutant spectrin $\alpha$ II domain in recessively inherited spherocytosis. Blood. 74(Suppl. 1):182a. (Abstr.)

6. Becker, P. S., W. T. Tse, S. E. Lux, and B. G. Forget. 1990. Identification of the molecular defect of $\beta$ spectrin in autosomal dominant hereditary spherocytosis (HS) associated with defective binding of protein 4.1, HS(Sp-4.1). Blood. 76(Suppl. 1):25a. (Abstr.)

7. Wolfe, L. C., K. M. John, J. C. Falcone, A. M. Byrne, and S. E. Lux. 1982. A genetic defect in the binding of protein 4.1 to spectrin in a kindred with hereditary spherocytosis. N. Engl. J. Med. 307:1367-1373.

8. Marchesi, S. L., L. Benoit, D. Beardsley, P. Becker, D. Speicher, and B Berman. 1992. Two families with spherocytosis and unstable $\beta$ spectrin. Blood. 80(Suppl. 1):276a. (Abstr.)

9. Hanspal, M., S. Yoon, H. Yu, J. S. Hanspal, S. Lambert, J. Palek, and J. Prchal. 1991. Molecular basis of spectrin and ankyrin deficiencies in severe hereditary spherocytosis: evidence implicating a primary defect of ankyrin. Blood. 77:165-173.

10. Lux, S. E., W. T. Tse, J. C. Menninger, K. M. John, P. Harris, O. Shalev, R. R. Chilcote, S. L. Marchesi, P. C. Watkins, V. Bennett, et al. 1990. Hereditary spherocytosis associated with deletion of human erythrocyte ankyrin gene on chromosome 8. Nature (Lond.). 345:736-739. 
11. Jarolim, P., V. Brabec, S. Lambert, S. C. Liu, Z. Zhou, and J. Palek. 1990. Ankyrin Prague: a dominantly inherited mutation of the regulatory domain of ankyrin associated with hereditary spherocytosis. Blood. 76(Suppl. 1):37a. (Abstr.)

12. Jarolim, P., P. Ruff, T. L. Coetzer, J. T. Prchal, S. K. Ballas, M. Poon, V. Brabec, and J. Palek. 1990. A subset of patients with dominantly inherited hereditary spherocytosis has a marked deficiency of the band 3 protein. Blood. 76(Suppl. 1):37a. (Abstr.)

13. Lux, S. E., C. Bedrosian, O. Shalev, M. Morris, J. Chasis, K. Davies, P. Savvides, and M. Telen. 1990. Deficiency of band 3 in dominant hereditary spherocytosis with normal spectrin content. Clin. Res. 38:300A. (Abstr.)

14. Prchal, J. T., Y. Guan, P. Jarolim, J. Palek, L. Showe, and L. Bertoli. 1991 Hereditary spherocytosis in a large family is linked with the band 3 gene and not with a-spectrin, b-spectrin or ankyrin. Blood. 78(Suppl. 1):81a. (Abstr.)

15. Low, P. S. 1986. Structure and function of the cytoplasmic domain of band 3: center of erythrocyte membrane-peripheral protein interactions. Biochim. Biophys. Acta. 864:145-167.

16. Tanner, M. J. A. 1993. Molecular and cellular biology of the erythrocyte anion exchanger (AE1). Semin. Hematol. 30:34-57.

17. Davis, L., S. E. Lux, and V. Bennett. 1989. Mapping the ankyrin-binding site of the human erythrocyte anion exchanger. J. Biol. Chem. 264:9665-9672.

18. Pasternack, G. R., R. A. Anderson, T. L. Leto, and V. T. Marchesi. 1985. Interactions between protein 4.1 and band 3. An alternative binding site for an element of the membrane skeleton. J. Biol. Chem. 260:3676-3683.

19. Yu, J., and T. L. Steck. 1975. Associations of band 3, the predominant polypeptide of the human erythrocyte membrane. J. Biol. Chem. 250:91769184.

20. Walder, J. A., R. Chatterjee, T. L. Steck, P. S. Low, G. F. Musso, E. T. Kaiser, P. H. Rogers, and A. Arnone. 1984. The interaction of hemoglobin with the cytoplasmic domain of band 3 of the human erythrocyte membrane. J. Biol. Chem. 259:10238-10246.

21. Dodge, J. T., C. Mitchell, and D. J. Hanahan. 1963. The preparation and chemical characteristics of hemoglobin-free ghosts of human erythrocytes. Arch. Biochem. Biophys. 100:119-130.

22. Jarolim, P., J. Palek, H. L. Rubin, J. T. Prchal, C. Korsgren, and C. M Cohen. 1992. Band 3 Tuscaloosa: Pro $^{327} \rightarrow \mathrm{Arg}^{327}$ substitution in the cytoplasmic domain of erythrocyte band 3 protein associated with spherocytic hemolytic anemia and partial deficiency of protein 4.2. Blood. 80:523-529.

23. Fairbanks, G., T. L. Steck, and D. F. H. Wallach. 1971. Electrophoretic analysis of the major polypeptides of the human erythrocyte membrane. Biochem istry. 10:2606-2617.

24. Laemmli, U. K. 1970. Cleavage of structural proteins during the assembly of the head of bacteriophage T4. Nature (Lond.). 227:680-685.

25. Jennings, L. K., L. K. Brown, and M. E. Dockter. 1985. Quantitation of protein 3 content of circulating erythrocytes at the single-cell level. Blood. 65:1256-1262.

26. Goosens, M., and Y. W. Kan. 1981. DNA analysis in the diagnosis of hemoglobin disorders. Methods Enzymol. 76:805-817.

27. Orita, M., H. Iwahana, H. Kanazawa, K. Hayashi, and T. Sekiya. 1989. Detection of polymorphisms of human DNA by gel electrophoresis as singlestrand conformation polymorphisms. Proc. Natl. Acad. Sci. USA 86:2766-2770.

28. Orita, M., Y. Suzuki, T. Sekiya, and K. Hayashi. 1989. Rapid and sensitive detection of point mutations and DNA polymorphisms using the polymerase chain reaction. Genomics. 5:874-879.

29. Corash, L. M., S. Piomelli, A. C. Chen, C. Seaman, and E. Gross. 1974 Separation of erythrocytes according to age on a simplified density gradient. $J$. Lab. Clin. Med. 84:147-152.

30. Palek, J., S. C. Liu, and P. A. Liu. 1978. Crosslinking of the nearest membrane protein neighbors in ATP depleted, calcium enriched and irreversibly sickled red cells. In Erythrocyte Membranes: Recent Clinical and Experimental Advances. Alan R. Liss, New York. pp. 75-88.

31. Corbett, J. D., and D. E. Golan. 1993. Band 3 and glycophorin are progressively aggregated in density-fractionated sickle and normal red blood cells. Evidence from rotational and lateral mobility studies. J. Clin. Invest. 91:208-217.

32. Yoshida, T. M., and B. G. Barisas. 1986. Protein rotational motion in solution measured by polarized fluorescence depletion. Biophys. J. 50:41-53.

33. Schofield, A. E., D. M. Reardon, and M. J. A. Tanner. 1992. Defective anion transport activity of the abnormal band-3 in hereditary ovalocytic red blood cells. Nature (Lond.). 355:836-838.

34. Morrison, M., W. Grant, H. T. Smith, T. J. Mueller, and L. Hsu. 1985. Catabolism of the anion transport protein in human erythrocytes. Biochemistry. 24:6311-6315

35. Tanner, M. J. A., P. G. Martin, and S. High. 1988. The complete amino acid sequence of the human erythrocyte membrane anion-transport protein deduced from the cDNA. Biochem. J. 256:703-712.

36. Lux, S. E., K. M. John, R. R. Kopito, and H. F. Lodish. 1989. Cloning and characterization of band 3 , the human erythrocyte anion-exchange protein (AE1). Proc. Natl. Acad. Sci. USA. 86:9089-9093.

37. Kopito, R. R., M. Anderson, and H. F. Lodish. 1987. Structure and organization of the murine band 3 gene. J. Biol. Chem. 262:8035-8040.

38. Casey, J. R., and A. F. Reithmeier. 1991. Analysis of the oligomeric state of band 3, the anion transport protein of the human erythrocyte membrane, by size exclusion high performance liquid chromatography. Oligomeric stability and origin of heterogeneity. J. Biol. Chem. 266:15726-15737.

39. Kunimoto, M., K. Shibata, and T. Miura. 1989. Comparison of the cytoskeleton fractions of rat red blood cells prepared with non-ionic detergents. $J$ Biochem. 105:190-195.

40. Golan, D. E. 1989. Red blood cell membrane protein and lipid diffusion. In Red Blood Cell Membranes. P. Agre and J. C. Parker, editors. Marcel Dekker, New York, pp. 367-400.

41. Matayoshi, E. D., and T. M. Jovin. 1991. Rotational diffusion of band 3 in erythrocyte membranes. I. Comparison of ghosts and intact cells. Biochemistry. 30:3525-3538.

42. Jay, D., and L. Cantley. 1986. Structural aspects of the red cell anion exchange protein. Ann. Rev. Biochem. 55:511-538.

43. Edwards, H. H., T. J. Mueller, et al. 1979. Distribution of transmembrane polypeptides in freeze fracture. Science (Wash. DC). 203:54-56.

44. Yu, J., and D. Branton. 1976. Reconstitution of intramembrane particles in recombinants of erythrocyte protein Band 3 and lipid: effects of spectrin-actin association. J. Biol. Chem. 73:3891-3895.

45. Gilman, J. G., M. E. Johnson, and N. Mishima. 1988. Four base-pair DNA deletion in human ${ }^{A} \gamma$ globin-gene promoter associated with low ${ }^{A} \gamma$ expression in adults. Brit. J. Haematol. 68:455-458.

46. Hanspal, M., and J. Palek. 1992. Biogenesis of normal and abnormal red blood cell membrane skeleton. Semin. Hematol. 29:305-319.

47. Groves, J. D., and M. J. A. Tanner. 1992. Glycophorin A facilitates the expression of human band 3-mediated anion transport in Xenopus oocytes. $J$. Biol. Chem. 267:22163-22170.

48. Wickner, W. T., and H. F. Lodish. 1985. Multiple mechanisms of protein insertion into and across membranes. Science (Wash. DC). 230:400-406.

49. Romans, A. Y., P. L. Yeagle, S. E. O’Connor, and C. M. Grisham. 1979. Interaction between glycophorin and phospholipids in recombined systems. $J$. Supramol. Structure 10:241-251.

50. Elgsaeter, A., D. M. Shotton, and D. Branton. 1976. Intramembrane particle aggregation in erythrocyte ghosts. II. The influence of spectrin aggregation. Biochim. Biophys. Acta. 426:101-122. 